\title{
The effect of sward maturity on the in vitro digestibility and methane production of sward components
}

\author{
C.J. Quinlan ${ }^{1}$, M.B. Lynch ${ }^{1}$, M. O'Brien ${ }^{2}$, A. Navarro ${ }^{2}$, T.M. Boland ${ }^{1}$ \\ ${ }^{1}$ University College Dublin, Dublin, Ireland \\ ${ }^{2}$ Teagasc, Grange, Dunsany, Co. Meath, Ireland \\ Email: conor.quinlan@ucdconnect.ie
}

Introduction Methane $\left(\mathrm{CH}_{4}\right)$ from enteric fermentation accounts for $13.2 \%$ of Irelands' total greenhouse gas (GHG) emissions (McGettigan et al., 2008). Grassland based production dominates Irish ruminant production systems with approximately $90 \%$ of agricultural land dedicated to grazing. Grass based mitigation strategies are required to assist Ireland meet its GHG reduction targets. Sward maturity and individual sward components may impact on enteric $\mathrm{CH}_{4}$ fermentation in grazing ruminants. The aim of this experiment was to asses the impact of maturity and individual sward components on in vitro digestibility and $\mathrm{CH}_{4}$ production.

Material and methods Perennial ryegrass plots $(7 \mathrm{~m} \times 1.5 \mathrm{~m})$ were closed on May $1^{\text {st }} 2009$ and harvested sequentially at 10 day intervals to give 5 harvest dates T1 (11/05/09), T2 (22/05/09), T3 (31/05/09), T4 (09/06/09) and T5 (19/06/09). The grass cuts were separated into leaf, stem and dead material, manually prior to drying. Samples were oven dried at $40^{\circ} \mathrm{C}$ for 48 hours, then ground to pass through a $1 \mathrm{~mm}$ screen. Individual $\mathrm{CH}_{4}$ emissions were measured using the in vitro rumen gas production technique of Mauricio et al. (1999). Rumen fluid was collected from three fistulated Friesian steers at 9.30am prior to feeding (60:40 grass silage to concentrate ration). Concentrate composition was: (g/kg) 830 barley. 100 soya, 50 molasses, 20 mineral and vitamins mix. Statistical analysis was performed using the mixed procedure of SAS with terms included for sward component, harvest date and their interaction. Linear and quadratic effects of harvest date were assessed separately for each sward component

Results Stem content within the harvested samples ranged from $0.20-0.61$ on a DM basis. There was a linear decrease in apparent DM digestibility $(\mathrm{aDMd})$ of leaf $(\mathrm{P}<0.001)$, stem $(\mathrm{P}<0.001)$ and dead material $(\mathrm{P}<0.05)$ as the season progressed. There was a quadratic relationship between harvest date and $\mathrm{CH}_{4}$ per $\mathrm{g} \mathrm{DM}$ incubated and digested for the leaf component $(\mathrm{P}<0.05)$ with production declining from $\mathrm{T} 1$ to $\mathrm{T} 3$ and increasing hereafter. There was a tendency for increased $\mathrm{CH}_{4}$ per $\mathrm{g}$ $\mathrm{DM}$ digested for the stem component as the season progressed $(\mathrm{P}=0.1)$. All sward components differed for all parameters measured $(\mathrm{P}<0.05)$ with the exception of $\mathrm{CH}_{4} / \mathrm{g} \quad \mathrm{DM}$ incubated, where there was no difference between leaf and stem components $(\mathrm{P}>0.05)$. An interaction was detected for aDMd $(\mathrm{P}<0.001)$.

Table 1 Effect of sward components on in vitro digestibility and methane production

\begin{tabular}{|c|c|c|c|c|c|c|c|c|}
\hline \multirow[t]{2}{*}{ Treatment } & \multicolumn{5}{|c|}{ Harvest } & \multicolumn{3}{|c|}{ P-value } \\
\hline & $\mathrm{T} 1$ & $\mathrm{~T} 2$ & T3 & $\mathrm{T} 4$ & T5 & s.e.m & Linear & Quadratic \\
\hline $\begin{array}{l}\text { Leaf } \\
\text { aDMd }\end{array}$ & $0.72^{\mathrm{a}}$ & $0.70^{\mathrm{b}}$ & $0.66^{\mathrm{bc}}$ & $0.64^{\mathrm{c}}$ & $0.59^{d}$ & 0.027 & $* * *$ & ns \\
\hline $\mathrm{CH}_{4} / \mathrm{g} \mathrm{DM}$ incubated & 28.9 & 24.9 & 19.6 & 25.2 & 24.7 & 1.85 & ns & $*$ \\
\hline $\begin{array}{l}\mathrm{CH}_{4} / \mathrm{g} \mathrm{DM} \text { digested } \\
\text { Stem }\end{array}$ & 40.0 & 36.1 & 29.6 & 39.7 & 42.4 & 2.94 & ns & $*$ \\
\hline $\mathrm{aDMd}$ & $0.58^{\mathrm{a}}$ & $0.47^{\mathrm{b}}$ & $0.45^{\mathrm{b}}$ & $0.46^{\mathrm{b}}$ & $0.45^{\mathrm{b}}$ & 0.022 & $* * *$ & $* * *$ \\
\hline $\mathrm{CH}_{4} / \mathrm{g} \mathrm{DM}$ incubated & 28.9 & 24.7 & 24.2 & 28.5 & 28.9 & 2.10 & ns & ns \\
\hline $\begin{array}{l}\mathrm{CH}_{4} / \mathrm{g} \text { DM digested } \\
\text { Dead }\end{array}$ & 50.0 & 51.7 & 54.7 & 62.3 & 64.7 & 4.93 & $\mathrm{P}=0.1$ & $\mathrm{~ns}$ \\
\hline $\mathrm{aDMd}$ & 0.40 & 0.38 & 0.37 & 0.36 & 0.37 & 0.016 & $*$ & ns \\
\hline $\mathrm{CH}_{4} / \mathrm{g} \mathrm{DM}$ incubated & 17.3 & 14.7 & 15.4 & 20.2 & 16.5 & 1.65 & ns & ns \\
\hline $\mathrm{CH}_{4} / \mathrm{g} \mathrm{DM}$ digested & 43.3 & 38.7 & 42.0 & 56.7 & 45.5 & 5.10 & ns & ns \\
\hline
\end{tabular}

Conclusions Over the range of growth stages assessed, digestibility declined and $\mathrm{CH}_{4}$ emissions remained largely constant. Changes in content of individual components in the sward, particularly the replacement of leaf tissue with stem would likely cause an increase in $\mathrm{CH}_{4}$ output per unit of DM digested. The effect of swards differing in maturity on in vitro $\mathrm{CH}_{4}$ production merits further study.

Acknowledgements Financial support for this research was provided under the National Development Plan, through the Research Stimulus Fund, administered by the Department of Agriculture, Fisheries \& Food, Ireland

\section{References}

Mauricio, R.M., Mould, F.L., Dhanoa, M.S., Owen, E., Channa, K.S. and Theodorou, M.K., 1999. Animal Feed Science and Technology. 79, 321-330.

McGettigan, M., P. Duffy, B. Hyde, and P. O’Brien. 2008. Ireland National Inventory Report 2008. Greenhouse Gas Emissions 1990-2006. Reported to The United Nations Framework Convention on Climate Change. Environmental Protection Agency, Johnstown Castle Estate, Wexford, Ireland 